\title{
EVALUATION OF MASSIVE PARALLEL SEQUENCING AS A DIAGNOSTIC TOOL FOR FAMILIAL HYPERCHOLESTEROLEMIA
}

\author{
Ilze Radoviča*\#, Rūdolfs Bērziņš*, Gustavs Latkovskis**, ***, ****, Dāvids Fridmanis*,

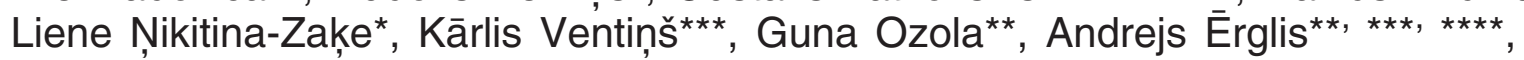 \\ and Jānis Kloviņšs* \\ * Latvian Biomedical Research and Study Centre, Rātsupītes iela 1, Rīga, LV-1067, LATVIA; \\ ilze@biomed.lu.Iv, ruchka135@gmail.com, davids@biomed.lu.Iv, lienik@biomed.lu.lv, klovins@biomed.lu.lv \\ ** Latvian Centre of Cardiology, Pauls Stradiṇš Clinical University Hospital, Rĩga, Dzirciema iela 20, LV-1007, LATVIA; \\ gustavs.latkovskis@gmail.com, g-ozola@inbox.lv, a.a.erglis@gmail.com \\ *** Faculty of Medicine, University of Latvia, Raiṇa bulv. 19, Rīga, LV-1586, LATVIA; \\ kvanv@inbox.Iv \\ ${ }^{* * *}$ Research Institute of Cardiology, University of Latvia, Pilsoṇu iela 13, Rīga, LV-1002, LATVIA \\ \# Corresponding author \\ Contributed by Jānis Kloviṇš
}

Familial hypercholesterolemia $(F H)$ is one of the most common single gene disorders, which is mostly inherited as an autosomal dominant trait. The physical signs of FH are elevated low density lipoprotein cholesterol (LDL-C), elevated total cholesterol (TC) levels and tendon xantomas. Identification and early treatment of affected individuals is desirable and in lack of physical symptoms DNA-based diagnosis provides confirmation of diagnosis and enables early patient management. The majority of FH cases are caused by mutations in four genes (APOB, LADLR, PCSK9, and LDLRAP1). There are commercial kits available for testing of the 20 most common FH causing mutations, but the spectrum of disease-causing mutations is quite diverse in various populations and these tests cover only a minority of disease-causing genetic variants. There is therefore a need to determine the full spectrum of mutations in LDLR, APOB, PCSK9 and LDLRAP1 genes in each population. Here we report mutations found in 16 patients with suspected $\mathrm{FH}$ in a sample from the Genome Database of the Latvian population enrolled at the Latvian Centre of Cardiology. We used the next generation sequencing approach to determine the full spectrum of mutations in coding regions of LDLR, APOB, PCSK9, and LDLRAP1. In total we found 22 missense mutations, from which only rs5742904 (Arg3527GIn) in APOB gene had been previously described as a FH-causing mutation confirming FH in one patient. Possible FH-causing mutations however were identified in the majority of patients. The conclusion is that the most commonly employed commercial mutation panel is not sufficient for diagnosis of FH patients and NGS can help to identify $\mathrm{FH}$-causing mutations in the Latvian population.

Key words: NGS, familial hypercholesterolemia, LDLR, APOB, PCSK9, LDLRAP1.

\section{INTRODUCTION}

Familial hypercholesterolemia (FH) was first described in 1920 (Burns, 1920). It affects about one in 500 individuals (Graham et al., 2005). FH is the most common single gene disorder and is mostly inherited as an autosomal dominant trait. The physical sign of FH is tendon xantomas, but these are not present in every family (Graham et al., 1999). Identification and early treatment of affected individuals is desirable and in lack of physical symptoms DNA-based diagnosis provides confirmation of diagnosis and enables early patient management (Graham et al., 2005). In the majority of FH cases individuals have defective low density lipopro- tein receptor (LDLR) which leads to accumulation of low density lipoprotein cholesterol (LDL-C) in plasma (Graham et al., 2005; Humphries et al., 2006b). Raised cholesterol concentrations in the blood are present from birth and lead to early development of atherosclerosis and coronary heart disease (DeMott, 2008). About half of men with FH will develop coronary heart disease by the age of 55. FH-affected women typically develop coronary heart disease about nine years later than men (Slack, 1969). The proportion of patients with FH identified and being treated is quite low, with most of these being young people (Humphries et al., 2006b). 
Hundreds of mutations in the LDLR gene have been reported and many of them cause $\mathrm{FH}$ (http://www.ucl.ac.uk/ldlr/Current/). A phenotypically similar condition is caused by defects in the Apolipoprotein B (APOB) gene (Graham et al., 2005), especially by mutations in the LDLR-binding domain of $A P O B$ (Fisher et al., 1999). This type of altered lipid level disease is called familial defective Apolipoprotein B (FDB). Various mutations in $A P O B$ gene are related to FDB and the most common one is Arg3527Gln (Chatzistefanidis et al., 2013). Gain-offunction mutations in protein convertase subtilisin/kexin type 9 (PCSK9) have been proposed to cause increased degradation of LDLR, and the resulting reduction of LDLR receptor number on the cell surface could be a cause of yet another type of monogenic Hypercholesterolemia (Humphries et al., 2006b). There is also evidence that functional mutations in low density lipoprotein adapter protein 1 (LDLRAP1) gene causing the recessive form of FH (Garcia et al., 2001).

Several FH diagnosis criteria have been used, namely MedPed/WHO, Simon Broom and Dutch criteria, which may include TC and LDL-C levels, presence of tendon xanthomas or arcus cornealis in young individuals, family history and, in the latter case, presence of functional mutations (Anonymous, 1999; Defesche et al., 2004; Humphries et al., 2006a;). Recent findings, however, suggest higher prevalence of $\mathrm{FH}$ than previously thought and therefore the true prevalence of $\mathrm{FH}$ should be investigated as it may be underestimated by the current FH diagnostic criteria (Benn et al., 2012). In this context, DNA-based evidence of functional mutations in LDLR, APOB and in PCSK9 genes is pivotal in making correct diagnosis (DeMott, 2008).

There are several commercial genetic test kits available for identification of most common FH-causing mutations. However, the spectrum of disease-causing mutations is quite diverse in many populations (Graham et al., 2005) and for that reason commercially available kits may not be effective for diagnosis of the FH patient group in all populations. The Elucigen FH20 ARMS kit, for example, tests 20 mutations, which is only $44 \%$ of the FH-causative mutations in the United Kingdom (Taylor et al., 2010). Therefore, determination of the most common mutations in LDLR, APOB, PCSK9, and LDLRAP1 in target populations might be required.

We conducted this pilot study to test whether the most common mutations used in commercially available tests occur in possible FH patients and patients with increased LDL-C in the Latvian population. In order to reach this goal our research was carried out in two stages. During the first stage we employed TaqMan probes to test seven relatively common mutations in the LDLR gene and one mutation in the $A P O B$ gene $(\operatorname{Arg} 3527 \mathrm{Gln})$. In the second stage we sequenced the coding regions of four $\mathrm{FH}$-causing genes (LDLR, APOB, PCSK9, and LDLRAPl) employing AmpliSeq library preparation technology and the Ion Torrent Personal Genome Machine (PGM) Next Generation Sequencing (NGS) system.

\section{MATERIALS AND METHODS}

Subjects. For this study we randomly selected 16 patients with elevated LDL-C (documented TC $7.0 \mathrm{mmol} / \mathrm{L}$ or higher and/or LDL-C $5.0 \mathrm{mmol} / \mathrm{L}$ or higher) from the Latvian Genome Database (LGDB), which on September of 2013 contained more than 22000 DNA samples $(\sim 1 \%$ of the Latvian population) (Ignatovica et al., 2011). In order to maintain consistency of clinical information, only patients recruited at the Latvian Centre of Cardiology were included in the study. Written informed consent was acquired from all LGDB participants. The study protocol was approved by the Central Medical Ethics Committee of Latvia (Protocols Nr. 2007 A-7, and 01-29.1/25).

Genotyping. For the purposes of our study we choose eight of the 20 most frequent functional mutations in $L D L R$ and $A P O B$ genes. All chosen mutations are included in the commercially available Elucigen FH20 ARMS kit and listed in the SNP database of the National Centre for Biotechnology Information (dbSNP, build 138): (rs5742904, rs139624145, rs28942078, rs121908024, rs121908039, rs28942084, rs121908027 and rs121908028) (Taylor et al., 2010). Prior to genotyping the concentration of DNA in the samples was normalised to $7 \mathrm{ng} / \mu \mathrm{l}$. The concentration measurements were acquired using a spectrophotometer NANODROP ND-1000. Genotyping was carried out using an Applied Biosystems TaqMan SNP Genotyping Assay with a modified protocol described earlier (Peculis et al., 2011). A total of eight mutations in 16 patients with $\mathrm{FH}$ were genotyped.

Next generation sequencing (NGS). In order to identify the overall functional mutation spectrum, all DNAs of the 16 patients were subjected to all exon sequencing of four FH-related genes. Sequencing was carried out at the Latvian Biomedical Research and Study Centre using Life Technologies Ion Torrent ${ }^{\mathrm{TM}}$ PGM equipment, which is based on semiconductor sequencing technology.

Target enrichment by PCR capture. Within the frame work of our research we developed an AmpliSeq ${ }^{\text {TM }}$ assay which, via multiplex PCR, provides the template for Ion Torrent $^{\mathrm{TM}}$ sequencing library preparation and enables rapid parallel sequencing of all exons of $L D L R, A P O B, P C S K 9$ and LDLRAPl genes. The Ion AmpliSeq ${ }^{\mathrm{TM}}$ Designer tool was used for custom assay primer design and separation in two compatible primer pools. Design was set up using a human (hg19) reference, pipeline version 1.2 for $200 \mathrm{bp}$ long amplicons. In total, 192 primer pairs were designed and mixed in two pools. Primer pools were manufactured by Life Technologies.

Library construction. An Invitrogen Qubit 2.0 Fluorometer was used for measurement of dsDNA concentration and acquired results were used for concentration normalisation to $5 \mathrm{ng} / \mu \mathrm{l}$. Standard AmpliSeq ${ }^{\mathrm{TM}}$ library Preparation protocol with DNA input of 10 ng (Release: 10 September 2012, Publication part Nr. MAN0006735) was used to prepare DNA libraries. The final library quantification was performed on an Agilent 2100 Bioanalyzer using High Sensi- 
tivity DNA chips (Agilent Technologies). After quantification the library dilution factor was calculated, the libraries were diluted to concentration of approximately $20 \mathrm{pM}$ and all 16 libraries were pooled together to ensure efficient usage of Ion chip space. Commercially available, platform specific barcodes were used during library preparation to distinguish patients after pooling of libraries (Ion Xpress ${ }^{\mathrm{TM}}$ Barcode Adapters).

Sequencing. An Ion OneTouch ${ }^{\mathrm{TM}} 200$ Template Kit v2 DL (Release: 12 September 2012, Publication Nr. MAN0006957) was used for template preparation and emulsion PCR. An Ion $\mathrm{PGM}^{\mathrm{TM}} 200$ Sequencing Kit (Release: 26 September 2012, Rev. F, Publication Nr. 4474246) and standard sequencing protocol were used for the sequencing procedure. One 314 chip was shared for all 16 libraries and predicted average coverage was $\sim 30 \times$ (according to recommendations of standard AmpliSeq protocol).

Data analysis. Acquired raw data was aligned to a human reference genome ( $\mathrm{Hg} 19)$ using Torrent suite 3.6.2 alignment plugin v3.6.56201. Variant calling plugin (variantCaller v3.6.63335) and Ion Reporter v1.6 online software (https://ionreporter.lifetechnologies.com/) were used to call and annotate detected variations within sequenced samples. Only non-synonymous coding mutations were further analysed, because these had the highest potential to have an effect on coded protein and thus on patient blood lipid levels. The National Centre for Biotechnology Information (NCBI, http://www.ncbi.nlm.nih.gov/), Human Gene Mutation Database (HGMD, http://www.hgmd.org/), Familial Hypercholesterolemia Variant Database (http://www.ucl.ac.uk/ugi/fh) as well as other online sources of information were used to manually verify the previous annotations of all missense mutations and annotate missense mutations unannotated by automatic tools. PolyPhen-2 v2.2.2r398, an online tool for human SNP functional effect prediction, was employed to predict possible functional effects of detected mutations if no information was found in any of the previously mentioned sources.

Verification with Sanger sequencing. The verification of NGS-detected mutations was performed by Sanger Sequencing on an ABI Prism 3130XL Genetic Analyzer (Applied Biosystems) using region specific primer sequences that were designed for the AmpliSeq assay.

\section{RESULTS}

For the purposes of this research we selected 16 patients from LGDB with elevated LDL-C levels. According to the MedPed and WHO criteria, seven patients (43.8\%) had probable $\mathrm{FH}$, seven patients $(43.8 \%)$ had possible $\mathrm{FH}$ and two patients $(12.4 \%)$ would not be classified as having FH (World Health Organization, 1999). 81.3\% of all patients had hypertension and $87.5 \%$ had coronary heart disease. In total, all patients had either hypertension or coronary heart disease and $68.8 \%$ had both. $62.5 \%$ of all patients had history of myocardial infarction (mean age of 52), and $31.3 \%$
CLINICAL CHARACTERISTICS OF THE STUDIED COHORT

\begin{tabular}{lc}
\hline \multicolumn{1}{c}{ Variable } & \\
\hline $\mathrm{n}$ & 16 \\
Mean age, years $\pm \mathrm{SD}(\min -\max )$ & $62.9 \pm 12.9(41-80)$ \\
Female gender, $\%$ & $56.3 \%$ \\
TC level, mmol/L $\pm \mathrm{SD}(\min -\max )$ & $8.0 \pm 1.0(6.7-10.4)$ \\
LDL-C level, $\mathrm{mmol} / \mathrm{L} \pm \mathrm{SD}(\min -\max )$ & $5.9 \pm 0.9(4.9-8.2)$ \\
BMI, $\mathrm{kg} / \mathrm{m}^{2} \pm \mathrm{SD}(\min -\max )$ & $29.9 \pm 5.5(18.8-42.5)$
\end{tabular}

of all patients had known relatives with coronary heart disease. Most of the patients had history of revascularisation (percutaneous coronary intervention in $75 \%$ and coronary artery bypass grafting in $12.5 \%$ of cases, with one patient having history of both). Clinical characteristics of our cohort are summarised in Table 1.

All selected patients were genotyped for the eight most frequent FH-causing mutations (Taylor et al., 2010). Only one the patients was a carrier of the $A P O B$ gene (rs5742904) mutation in heterozygous state, thereby providing genetic confirmation of disease in $6.3 \%$ of cases.

We then performed NGS of all exons for four genes that are known to cause FH. Sequencing data analysis revealed that patients of the selected cohort were carriers of 29 missense mutations in total. One of these mutations (rs5742904) was already identified during RT-PCR analysis. We confirmed 21 mutations by Sanger sequencing. The remaining seven mutations were not confirmed with Sanger sequencing, and were either AmpliSeq PCR mistakes or aroused by mutation calling algorithms. All 22 verified missense mutations found in the 16 Latvian FH patients are summarised in Table 2 .

Further data mining through various resources unveiled that nine of the mutations were already recorded in the HGMD Database (http://www.hgmd.org/), one was recorded in the Hypercholesterolemia (FH) Variant Database UCL (http://www.ucl.ac.uk/ldlr) and four were reported by various authors as associated with different lipid traits. Eight, however, had no reports of association with lipid metabolism alterations. One mutation rs5742904, located in the $A P O B$ gene, were reported to cause $\mathrm{FH}$ and was found in one patient (Soria et al., 1989; Taylor et al., 2010; Chatzistefanidis et al., 2013;). Another mutation (rs41291058) in LDLRAPl gene had been linked to autosomal recessive $\mathrm{FH}$ (Garcia et al., 2001; Eden et al., 2002). Four mutations (rs1367117, rs679899, rs533617 and rs562556), located in the $A P O B$ and PCSK9 genes, in the HGMD database were reported to be associated with altered lipid levels or altered binding efficiency (Shioji et al., 2004; Humphries et al., 2006b; Liao et al., 2008; Makela et al., 2012; Calandra et al., 2011; Al-Waili et al., 2013). Another mutation (rs505151) in the PCSK9 gene was previously associated with atherosclerosis (Humphries et al., 2006b; Kotowski et al., 2006). Two variants rs676210 from $A P O B$ and rs11591147 from PCSK9 were associated, respectively, with the protective 
MISSENSE MUTATIONS FOUND IN FAMILIAL HYPERCHOLESTEROLEMIA PATIENTS FROM LATVIA

\begin{tabular}{|c|c|c|c|c|c|c|c|c|c|c|c|}
\hline Rs code & $\mathrm{Chr}$ & Gene & $\begin{array}{c}\text { AA } \\
\text { substitution }\end{array}$ & $\begin{array}{r}\text { Ref. } \\
\text { allele }\end{array}$ & $\begin{array}{c}\text { Alt. } \\
\text { allele }\end{array}$ & $\begin{array}{c}\text { Count } \\
\text { of } \\
\text { hetero- } \\
\text { zygouts }\end{array}$ & $\begin{array}{c}\text { Count } \\
\text { of } \\
\text { homo- } \\
\text { zygouts }\end{array}$ & $\begin{array}{c}\text { Alt. } \\
\text { allele } \\
\text { frequency }\end{array}$ & $\begin{array}{c}\text { Alt. allele } \\
\text { frequency in } \\
\text { population } \\
(\mathrm{NCBI})\end{array}$ & $\begin{array}{c}\text { Phenotype from } \\
\text { HGMD }\end{array}$ & References \\
\hline rs1367117 & 2 & $A P O B$ & Thr98Ile & G & A & 6 & 1 & 25,0 & 20.5 & $\begin{array}{l}\text { Increased cholesterol } \\
\text { levels }\end{array}$ & $\begin{array}{l}\text { (Liao et al., 2008; Calandra et } \\
\text { al., 2011; Makela et al., 2012) }\end{array}$ \\
\hline rs146152405 & 2 & $A P O B$ & Arg214His & $\mathrm{C}$ & A & 1 & 0 & 3,1 & 0.1 & & - \\
\hline rs12713844 & 2 & $A P O B$ & Asp1113His & $\mathrm{C}$ & G & 2 & 0 & 6,3 & 0.3 & & - \\
\hline rs568413 & 2 & $A P O B$ & Cys1422Tyr & $\mathrm{C}$ & $\mathrm{T}$ & 0 & 2 & 12.5 & 0.1 & & - \\
\hline rs 151009667 & 2 & $A P O B$ & Arg1689His & $\mathrm{C}$ & $\mathrm{T}$ & 1 & 0 & 3,1 & 0.1 & & - \\
\hline rs533617 & 2 & $A P O B$ & His1923Arg & $\mathrm{T}$ & $\mathrm{C}$ & 1 & 0 & 3,1 & 2.0 & $\begin{array}{l}\text { Altered binding } \\
\text { affinity }\end{array}$ & (Makela et al., 2012) \\
\hline rs72653092 & 2 & $A P O B$ & Ser2429Thr & A & $\mathrm{T}$ & 1 & 0 & 3,1 & 0.1 & & - \\
\hline rs1801696 & 2 & $A P O B$ & Glu2566Lys & $\mathrm{C}$ & $\mathrm{T}$ & 1 & 0 & 3,1 & 0.2 & & - \\
\hline rs676210 & 2 & $A P O B$ & Pro2739Leu & G & A & 4 & 1 & 18,9 & 33.8 & $\begin{array}{l}\text { Hypocholesterol- } \\
\text { aemia, association } \\
\text { with }\end{array}$ & (Makela et al., 2012) \\
\hline rs5742904 & 2 & $A P O B$ & $\operatorname{Arg} 3527 \mathrm{Gln}$ & $\mathrm{C}$ & $\mathrm{T}$ & 1 & 0 & 3,1 & 0.1 & $\begin{array}{l}\text { Hypercholesterol- } \\
\text { aemia }\end{array}$ & $\begin{array}{c}\text { (Soria et al., 1989; Taylor et al., } \\
\text { 2010; Chatzistefanidis } \text { et al., } \\
\text { 2013) }\end{array}$ \\
\hline rs1801701 & 2 & $A P O B$ & Arg3638Gln & $\mathrm{C}$ & $\mathrm{T}$ & 3 & 0 & 9,4 & 4.9 & & (Calandra et al., 2011) \\
\hline rs 1042031 & 2 & $A P O B$ & Glu4181Lys & $\mathrm{C}$ & $\mathrm{T}$ & 6 & 0 & 18,8 & 15.3 & & $\begin{array}{c}\text { (Liao et al., 2008; Calandra et } \\
\text { al., 2011; Gaudreault et al., } \\
\text { 2011; Makela et al., 2012) }\end{array}$ \\
\hline rs 1801702 & 2 & $A P O B$ & Arg4270Tyr & $\mathrm{C}$ & G & 1 & 0 & 3,1 & 6.2 & & (Liao et al., 2008) \\
\hline rs 1042034 & 2 & $A P O B$ & Ser4338Asn & $\mathrm{C}$ & $\mathrm{T}$ & 4 & 11 & 81,3 & 66.2 & & (Makela et al., 2012) \\
\hline rs11669576 & 19 & LDLR & Ala264Thr & G & A & 1 & 0 & 3,1 & 7.6 & & (Lamsa et al., 2008) \\
\hline rs41291058 & 1 & LDLRAP1 & Arg238Trp & $\mathrm{C}$ & $\mathrm{T}$ & 1 & 0 & 3,1 & 2.4 & $\begin{array}{l}\text { Hypercholesterol- } \\
\text { aemia, autosomal } \\
\text { recessive }\end{array}$ & (Eden et al., 2002) \\
\hline rs11591147 & 1 & PCSK 9 & Arg46Leu & G & $\mathrm{T}$ & 1 & 0 & 3,1 & 0.9 & $\begin{array}{l}\text { Coronary heart } \\
\text { disease, reduced risk, } \\
\text { association with }\end{array}$ & (Benn et al., 2010; Cohen et al., \\
\hline rs11583680 & 1 & PCSK9 & Ala53Val & $\mathrm{C}$ & $\mathrm{T}$ & 2 & 1 & 12,5 & 9.0 & & (Fasano et al., 2007) \\
\hline rs562556 & 1 & PCSK 9 & Ile474Val & A & G & 7 & 1 & 28.1 & 14.7 & $\begin{array}{l}\text { High LDL choles- } \\
\text { terol, association with }\end{array}$ & $\begin{array}{l}\text { (Al-Waili et al., 2013; } \\
\text { Humphries et al., 2006b; } \\
\text { Shioji et al., 2004) }\end{array}$ \\
\hline rs505151 & 1 & PCSK 9 & Glu670Gly & A & $\mathrm{G}$ & 2 & 1 & 12.5 & 9.8 & $\begin{array}{c}\text { Atherosclerosis, } \\
\text { severity, association } \\
\text { with }\end{array}$ & $\begin{array}{l}\text { (Humphries et al., 2006b; } \\
\text { Kotowski et al., 2006) }\end{array}$ \\
\hline
\end{tabular}

Chr - chromosome; AA substitution - amino acid substitution; Ref. allele - nucleotide of reference allele (Hg19); Alt allele - nucleotide of alternative allele.

phenotype, hipocholesterolemia, and reduced risk for coronary heart disease (Cohen et al., 2004; Benn et al., 2010; Makela et al., 2012). We also found a mutation in the PCSK9 gene (rs11583680) that was described in Familial Hypercholesterolemia (FH) Variant Databases UCL (http://www.ucl.ac.uk/ldlr) as a benign polymorphism (Fasano et al., 2007). Three APOB gene variants found in our study group (rs1801701, rs1042031 and rs1801702) have been described by various authors as associated with different lipid traits and one as benign (rs1042034) (Liao et al., 2008; Makela et al., 2012; Calandra et al., 2011; Gaudreault et al., 2011).
There was no information in the available resources regarding the association of eight missense mutations found in our data. The majority of these mutations were located in the $A P O B$ gene. In order to estimate the possible effect of the identified mutations on coded proteins we performed functional effect prediction using the online tool PolyPhen-2 v2.2.2r398 (http://genetics.bwh.harvard.edu/pph2/). This showed that one mutation (rs12713844) is possibly damaging and three mutations are possibly benign (rs1801696, rs568413 and rs11669576). Unfortunately, because of the lack of information PolyPhen-2 was not able to predict effects for the other mutations. 


\section{DISCUSSION}

In order to test the diagnostic efficiency of the commercially available UK population-based FH diagnosis panel for the Latvian population, we began this study by genotyping of 16 FH patients using TaqMan RT-PCR technology. We tested for eight of the most frequent mutations of 20 that are used in the commercially available $\mathrm{FH}$ diagnosis panel. As a result we were able to gain genetic confirmation of FH diagnosis in only one case, where the heterozygous mutation in $A P O B$ gene (rs5742904) was detected. Thus, the employed mutation panel efficiency in the Latvian population was only $6.3 \%$, which is too low to be considered a cost effective diagnostic tool. This result suggests that simplified employment of the panel for the most frequent mutations used for diagnosis of $\mathrm{FH}$ in the Latvian population is not as effective as in the UK, where $44 \%$ of FH cases can be confirmed. This also suggests that it is necessary to identify the most frequent FH causing mutations in the Latvian population, thus enabling the generation of a simple and inexpensive mutation panel for diagnosis of FH that is regionally efficient.

Since the efficiency of the genotyping was low, we performed sequencing of the coding regions of four $\mathrm{FH}$ related genes (LDLR, APOB, PCSK9, and LDLRAP1) using IonTorrent NGS technology. The goal of this analysis was to identify missense mutations that were missed by TaqMan probes. The data acquired from this analysis revealed that none of other most commonly tested mutations for diagnosis of FH in other countries (Taylor et al., 2010) were present. However, we found 21 other missense mutations, which are considered as less common. These results clearly show that mutation distributions differ between populations and that an alternative mutations panel could be used to confirm
FH diagnosis in Latvian population. The majority of identified 22 missense mutations in most cases were located in the APOB gene. We found one mutation in the LDLRAPl gene, which according to literature is associated with the autosomal recessive form of $\mathrm{FH}$, but since this mutation was found in heterozygous state, direct genetic confirmation for FH diagnosis could not be established. However, it is possible that this mutation may cause $\mathrm{FH}$ in these patients, especially in combination with other mutations.

Our detailed sequence analysis identified four rare missense mutations that have been previously reported as associated with elevated lipid levels or also found in FH patients: rs533617, rs1801701, rs1801702 and rs505151. Similarly, one mutation (rs12713844) was determined by PolyPhen-2 as potentially damaging. Another four rare mutations (rs146152405, rs568413, rs151009667 and rs72653092) have no records of their linkage to $\mathrm{FH}$. The majority of these mutations were found only in single individuals and thus can be considered as involved in the progression of disease. However, it is possible that at least some of them are benign in their nature, and further investigation of their functional effect and family based analysis is required. In total, eight patients $(50.0 \%)$ from our study carry the above mentioned mutations (Table 3).

Four more common variants (rs1357117, rs679899, rs1042031, and rs562556) have been associated with increased LDL-C or altered APOB levels (Shioji et al., 2004; Humphries et al., 2006b; Liao et al., 2008; Calandra et al., 2011; Gaudreault et al., 2011; Makela et al., 2012; Al-Waili et al., 2013). There is no information available regarding their role in FH onset, but since there is an association with altered lipid levels and they have been detected in FH patients of various populations, it is possible that at least some

Table 3 DISTRIBUTION OF FH CAUSING AND POSSIBLY INFLUENCING MUTATIONS IN THE STUDIED COHORT

\begin{tabular}{l|c|c|c|c|c}
\hline & Patient & Age & $\begin{array}{c}\text { FH causative } \\
\text { mutations }\end{array}$ & $\begin{array}{c}\text { Rare mutations with possible impact } \\
\text { on phenotype }\end{array}$ & Common associated variants \\
\hline no FH & L8 & 78 & & & APOB(T98I, A618V) \\
& L11 & 73 & LDLRAP1(R238W) & APOB(R4270Y, R214H), PCSK9(E670G) & APOB(A618V) \\
\hline possible & L2 & 77 & & APOB(D1113H, R3638Q) & APOB(T98I, A618V) \\
FH & L4 & 49 & & APOB(A618V, E4181K), PCSK9(I474V) \\
& L5 & 69 & APOB(H1923R) & APOB(A618V, E4181K) \\
& L7 & 76 & & APOB(T98I), PCSK9(I474V) \\
& L9 & 80 & & PCSK9(E670G), APOB(C1422Y) & APOB(T98I, A618V, E4181K), PCSK9(I474V) \\
& L12 & 62 & & APOB(R3638Q, S2429T, C1422Y) & APOB(T98I, A618V, E4181K), PCSK9(I474V) \\
\hline probable & L16 & 62 & APOB(R3527Q) & APOB(A618V) \\
FH & L3 & 74 & & PCSK9(E670G) & APOB(A618V), PCSK9(I474V) \\
& L6 & 44 & & & APOB(A618V, E4181K), PCSK9(I474V) \\
& L10 & 51 & & APOB(T98I, A618V), PCSK9(I474V) & APOB(T98I)
\end{tabular}

Mutations in homozygous state are marked bold. FH, famililal hypercholesterolemia. 
of them can influence the progression of disease, especially in combination with rare mutations. In order to confirm this, however, research on the functional effects of these mutations should be carried out. In total, 14 patients $(87.5 \%)$ from our study carry the above mentioned mutations (Table 3).

In conclusion, we detected only one out of eight very well-known FH causing mutations in our FH patient cohort. Further analysis based on targeted NGS was able to confirm FH diagnosis for one patient $(6.3 \%)$. Mutations that possibly can alter LDL-C levels were found in eight patients. However, since our cohort is quite small, the estimated mutation frequencies cannot be extrapolated to the whole population, and further NGS-based investigation is needed to identify the most common FH-causing mutations in our population. Information of this kind would grant the opportunity to create a cost effective mutation detection panel for diagnosis of $\mathrm{FH}$ in the Latvian population. We also propose the NGS-based targeted sequencing panel as the most sensitive diagnostic tool available for the diagnosis of $\mathrm{FH}$.

\section{ACKNOWLEDGMENTS}

We acknowledge the Genome Database of Latvian Population, Latvian Biomedical Research and Study Centre and Latvian Centre of Cardiology for providing data and DNA samples. This work was supported by ERDF Project No. 2010/0311/2DP/2.1.1.1.0/10/APIA/VIAA/022.

\section{REFERENCES}

Al-Waili, K., Al-Zidi, W. A., Al-Abri, A. R., Al-Rasadi, K., Al-Sabti, H. A., Shah, K., Al-Futaisi, A., Al-Zakwani, I., Banerjee, Y. (2013). Mutation in the PCSK9 gene in Omani Arab subjects with autosomal dominant hypercholesterolemia and its effect on PCSK9 protein structure. Oman. Med. J., 28, 48-52.

Anonymous (1999). Familial Hypercholesterolemia: Report of a Second WHO Consultation. WHO/HGN/FH/Cons/99.2, Geneva. 16 pp.

Benn, M., Nordestgaard, B. G., Grande, P., Schnohr, P., Tybjaerg-Hansen, A. (2010). PCSK9 R46L, low-density lipoprotein cholesterol levels, and risk of ischemic heart disease: 3 independent studies and meta-analyses. $J$. Amer. Coll. Cardiol., 55, 2833-2842.

Benn, M., Watts, G. F., Tybjaerg-Hansen, A., Nordestgaard, B.G. (2012). Familial hypercholesterolemia in the danish general population: Prevalence, coronary artery disease, and cholesterol-lowering medication. $J$. Clin. Endocrinol. Metab., 97, 3956-3964.

Burns, F. (1920). A contribution to the study of the etiology of xanthomata. Arch. Derm. Syph., 2, 415-429.

Calandra, S., Tarugi, P., Speedy, H. E., Dean, A. F., Bertolini, S., Shoulders, C. C. (2011). Mechanisms and genetic determinants regulating sterol absorption, circulating LDL levels, and sterol elimination: Implications for classification and disease risk. J. Lipid. Res., 52, 1885-1926.

Chatzistefanidis, D., Markoula, S., Vartholomatos, G., Milionis, H., Miltiadous, G., Georgiou, I., Elisaf, M., Kyritsis, A. (2013). First detection of hypercholesterolemia causing ApoB-100 R3527Q mutation in a family in Greece. Gen. Syndromes. Gene Ther., 4, 6.

Cohen, J. C., Kiss, R. S., Pertsemlidis, A., Marcel, Y. L., McPherson, R., Hobbs, H. H. (2004). Multiple rare alleles contribute to low plasma levels of HDL cholesterol. Science, 305, 869-872.
Defesche, J. C., Lansberg, P. J., Umans-Eckenhausen, M. A., Kastelein, J. J. (2004). Advanced method for the identification of patients with inherited hypercholesterolemia. Semin. Vasc. Med., 4, 59-65.

DeMott, K., Nherera, L., Shaw, E. J., Minhas, R., Humphries, S. E., Kathoria, M., Ritchie, G., Nunes, V., Davies, D., Lee, P., McDowell, I., Neil, A., Qureshi, N., Rowlands, P., Seed, M., Stracey, H., Thorogood, M., Watson, M. (2008). Clinical Guidelines and Evidence Review for Familial hypercholesterolaemia: The identification and management of adults and children with familial hypercholesterolaemia. London: National Collaborating Centre for Primary Care and Royal College of General Practitioners.

Eden, E. R., Patel, D. D., Sun, X. M., Burden, J. J., Themis, M., Edwards, M., Lee, P., Neuwirth, C., Naoumova, R. P., Soutar, A. K. (2002). Restoration of LDL receptor function in cells from patients with autosomal recessive hypercholesterolemia by retroviral expression of ARH1. J. Clin. Invest., 110, 1695-1702.

Fasano, T., Cefalu, A. B., Di Leo, E., Noto, D., Pollaccia, D., Bocchi, L., Valenti, V., Bonardi, R., Guardamagna, O., Averna, M., Tarugi, P. (2007). A novel loss of function mutation of PCSK9 gene in white subjects with low-plasma low-density lipoprotein cholesterol. Arterioscler. Thromb. Vasc. Biol., 27, 677-681.

Fisher, E., Scharnagl, H., Hoffmann, M. M., Kusterer, K., Wittmann, D., Wieland, H., Gross, W., Marz, W. (1999). Mutations in the apolipoprotein (apo) B-100 receptor-binding region: Detection of apo B-100 (Arg3500 - Trp) associated with two new haplotypes and evidence that apo B-100 (Glu3405-Gln) diminishes receptor-mediated uptake of LDL. Clin. Chem., 45, 1026-1038.

Garcia, C. K., Wilund, K., Arca, M., Zuliani, G., Fellin, R., Maioli, M., Calandra, S., Bertolini, S., Cossu, F., Grishin, N., Barnes, R., Cohen, J. C., Hobbs, H. H. (2001). Autosomal recessive hypercholesterolemia caused by mutations in a putative LDL receptor adaptor protein. Science, 292, 1394-1398.

Gaudreault, N., Ducharme, V., Lamontagne, M., Guauque-Olarte, S., Mathieu, P., Pibarot, P., Bosse, Y. (2011). Replication of genetic association studies in aortic stenosis in adults. Amer. J. Cardiol., 108, 1305-1310.

Graham, C. A., McClean, E., Ward, A. J., Beattie, E. D., Martin, S., O'Kane, M., Young, I. S., Nicholls, D. P. (1999). Mutation screening and genotype:phenotype correlation in familial hypercholesterolaemia. Atherosclerosis, 147, 309-316.

Graham, C. A., McIlhatton, B. P., Kirk, C. W., Beattie, E. D., Lyttle, K., Hart, P., Neely, R. D., Young, I. S., Nicholls, D. P. (2005). Genetic screening protocol for familial hypercholesterolemia which includes splicing defects gives an improved mutation detection rate. Atherosclerosis, 182, 331-340.

Harada-Shiba, M., Takagi, A., Miyamoto, Y., Tsushima, M., Ikeda, Y., Yokoyama, S., Yamamoto, A. (2003). Clinical features and genetic analysis of autosomal recessive hypercholesterolemia. J. Clin. Endocrinol. Metab., 88, 2541-2547.

Humphries, S., Whittall, R., Hubbart, C., Maplebeck, S., Cooper, J., Soutar, A., Naoumova, T., Thompson, G., Seed, M., Durrington, P., Miller, J. P., Betteridge, D. J., Neil, H. A. Simon Broome Familial Hyperlipidaemia Register Group and Scientific Steering Committee (2006a). Genetic causes of familial hypercholesterolaemia in patients in the UK: Relation to plasma lipid levels and coronary heart disease risk. J. Med. Genet., 43, 943-949.

Humphries, S. E., Whittall, R. A., Hubbart, C. S., Maplebeck, S., Cooper, J. A., Soutar, A. K., Naoumova, R., Thompson, G. R., Seed, M., Durrington, P. N., Miller, J. P., Betteridge, D. J., Neil, H. A.; Simon Broome Familial Hyperlipidaemia Register Group and Scientific Steering Committee. (2006b). Genetic causes of familial hypercholesterolaemia in patients in the UK: Relation to plasma lipid levels and coronary heart disease risk. $J$. Med. Genet., 43, 943-949.

Ignatovica, V., Latkovskis, G., Peculis, R., Megnis, K., Schioth, H. B., Vaivade, I., Fridmanis, D., Pirags, V., Erglis, A., Klovins, J. (2011). Single nucleotide polymorphisms of the purinergic 1 receptor are not associated 
with myocardial infarction in a Latvian population. Mol. Biol. Rep., 39, 1917-1925.

Kotowski, I. K., Pertsemlidis, A., Luke, A., Cooper, R. S., Vega, G. L., Cohen, J. C., Hobbs, H. H. (2006). A spectrum of PCSK9 alleles contributes to plasma levels of low-density lipoprotein cholesterol. Amer. J. Hum. Genet., 78, 410-422.

Lamsa, R., Helisalmi, S., Herukka, S. K., Tapiola, T., Pirttila, T., Vepsalainen, S., Hiltunen, M., Soininen, H. (2008). Genetic study evaluating $L D L R$ polymorphisms and Alzheimer's disease. Neurobiol. Aging, 29, $848-855$

Liao, Y. C., Lin, H. F., Rundek, T., Cheng, R., Hsi, E., Sacco, R. L., Juo, S. H. (2008). Multiple genetic determinants of plasma lipid levels in Caribbean Hispanics. Clin. Biochem., 41, 306-312.

Makela, K. M., Seppala, I., Hernesniemi, J. A., Lyytikainen, L. P., Oksala, N., Kleber, M. E., Scharnagl, H., Grammer, T. B., Baumert, J., Thorand, B., Jula, A., Hutri-Kähönen, N., Juonala, M., Laitinen, T., Laaksonen, R., Karhunen, P. J., Nikus, K. C., Nieminen, T., Laurikka, J., Kuukasjärvi, P., Tarkka, M., Viik, J., Klopp, N., Illig, T., Kettunen, J., Ahotupa, M., Viikari, J. S., Kähönen, M., Raitakari, O. T., Karakas, M., Koenig, W., Boehm, B. O., Winkelmann, B. R., März, W., Lehtimäki, T. (2012). Genome-wide association study pinpoints a new functional apolipoprotein B variant influ- encing oxidized low-density lipoprotein levels but not cardiovascular events: AtheroRemo Consortium. Circ. Cardiovasc. Genet., 6, 73-81.

Peculis, R., Latkovskis, G., Tarasova, L., Pirags, V., Erglis, A., Klovins, J. (2011). A nonsynonymous variant $\mathrm{I} 248 \mathrm{~L}$ of the adenosine A3 receptor is associated with coronary heart disease in a Latvian population. DNA Cell Biol., 30, 907-911.

Shioji, K., Mannami, T., Kokubo, Y., Inamoto, N., Takagi, S., Goto, Y., Nonogi, H., Iwai, N. (2004). Genetic variants in PCSK9 affect the cholesterol level in Japanese. J. Hum. Genet., 49, 109-114.

Slack, J. (1969). Risks of ischaemic heart-disease in familial hyperlipoproteinaemic states. Lancet, 2, 1380-1382.

Soria, L. F., Ludwig, E. H., Clarke, H. R., Vega, G. L., Grundy, S. M., McCarthy, B. J. (1989). Association between a specific apolipoprotein B mutation and familial defective apolipoprotein B-100. Proc. Natl. Acad. Sci. U.S.A., 86, 587-591.

Taylor, A., Wang, D., Patel, K., Whittall, R., Wood, G., Farrer, M., Neely, R. D., Fairgrieve, S., Nair, D., Barbir, M., Jones, J. L., Egan, S., Everdale, R., Lolin, Y., Hughes, E., Cooper, J. A., Hadfield, S. G., Norbury, G., Humphries, S. E. (2010). Mutation detection rate and spectrum in familial hypercholesterolaemia patients in the UK pilot cascade project. Clin. Genet., 77, 572-580.

Received 1 December 2013

\section{LIELA APJOMA PARALĒLĀ SEKVENĒSANA KĀ VISPILNİGĀKAIS DIAGNOSTIKAS VEIDS IEDZIMTAI HIPERHOLESTERINĒMIJAI}

Iedzimta hiperholesterinēmija (IH) ir viena no visbiežāk sastopamajām monogēnajām slimībām, kas lielākoties tiek pārmantota kā autosomāli dominanta pazīme. IH klīniskie simptomi ir paaugstināts zema blīvuma lipoproteīna holesterols (ZBL-H), paaugstināts kopējais holesterols $(\mathrm{KH})$ un tendon xantomas. Skarto indivīdu savlaicīga identifikācija un ārstēšana ir ḷoti nepieciešama, un gadījumos, kad iztrūkst klīniskie simptomi, DNS analīzes dod iespēju apstiprināt diagnozi un veikt savlaicīgu pacienta aprūpi. Lielāko daḷu IH gadījumu izraisa mutācijas četros gēnos (APOB, LADLR, PCSK9 un LDLRAP1). Ir zināmi komerciāli pieejami testi, kuros ietilpst 20 visbiežāk izplatīto IH izraisošo mutāciju testēšana. Slimību izraisošo mutāciju sastopamība ir atškirīga dažādās populācijās, un tā kā šie testi ietver tikai nelielu daḷu no IH izraisošajiem ǵenētiskajiem variantiem, ir nepieciešams apzināt pilnu mutāciju spektru LDLR, APOB, PCSK9 un LDLRAP1 gēnos katrā populācijā. Šeit mēs sniedzam ieskatu par mutācijām, kas atrastas 16 pacientiem, kuriem ir aizdomas par IH. Pacientu paraugi ievākti sadarbībā ar Latvijas Cilvēka genoma datubāzi un Latvijas Kardioloǵijas centru. Lai apzinātu visas kodējošās mutācijas $L D L R$, APOB, PCSK9 un LDLRAP1 gēnos, mēs izmantojām mērkētu nākamās paaudzes sekvenēšanas pieeju. Rezultātā tika atrastas 22 dažādas mutācijas, kas izraisa aminoskābju nomaiņas, un IH diagnoze tika apstiprināta vienam pacientiem (6.3\%). Astoṇiem pacientiem tika atrastas arī iespējams IH izraisošas mutācijas. Var secināt, ka komerciālajos IH testos pārbaudāmo mutāciju komplekti ir nepietiekami IH diagnostikai un nākamās paaudzes sekvenēšanas pieeja var palīdzēt identificēt mutācijas, kas izraisa IH Latvijas populācijā. 